\title{
Evaluation of critical nitrogen and phosphorus models for maize under full and limited irrigation conditions
}

\author{
Koffi Djaman, ${ }^{1}$ Suat Irmak ${ }^{2}$ \\ ${ }^{1}$ Africa Rice Center (AfricaRice), Saint Louis, Senegal; ${ }^{2}$ Department of Biological Systems Engineering, \\ University of Nebraska-Lincoln, Lincoln, NE, USA
}

\begin{abstract}
Proper nitrogen $(\mathrm{N})$ fertiliser application rates and timing of application, coupled with optimum irrigation management can improve the sustainability of maize production and reduce the risk of environmental contamination by nutrients. The impact of full and limited irrigation and rainfed conditions on in-season maize (Zea mays L.) shoot biomass nutrient concentration and critical $\mathrm{N}$ and phosphorus $(\mathrm{P})$ indices were evaluated using a combination of measured nutrients and critical $\mathrm{N}$ and $\mathrm{P}$ models in south central Nebraska in 2009 and 2010. Four irrigation treatments [fully-irrigated treatment (FIT), 75\% FIT, 60\% FIT and 50\% FIT) and rainfed] were imposed. Irrigation regimes impacted the shoot biomass $\mathrm{N}$ concentration. The shoot biomass $\mathrm{N}$ concentration was above the critical N (Ncrit) concentration throughout the growing season under FIT and 75\% FIT and was below the Ncrit value for the most limited irrigation (60\% FIT and 50\% FIT) and rainfed treatments. Nitrogen nutrient index (NNI) varied from 0.68 to 2.0. Biomass $\mathrm{N}$ concentration was below Ncrit [i.e., $\mathrm{NNI}<1$ ] from 105 days after planting (DAP) to harvest under rainfed and 50\% FIT and from 114 DAP to harvest under $60 \%$ FIT. Overall, the FIT and the $75 \%$ FIT had NNI values greater than 1.0 throughout both growing seasons. Phosphorus concentration, which decreased with biomass accumulation and irrigation amounts, varied from 1.0 to $4.8 \mathrm{~g} \mathrm{~kg}^{-1}$, with FIT having the highest biomass P concentration. The critical $\mathrm{N}$ model combined with NNI can be used to evaluate $\mathrm{N}$ and $\mathrm{P}$ in maize for in-season nutrient diagnosis under the conditions presented in this research.
\end{abstract}

\footnotetext{
Correspondence: Koffi Djaman, Africa Rice Center (AfricaRice), BP. 96 Saint Louis, Senegal.

Tel.: +221780165660 .

E-mail:k.djaman@cgiar.org

Key words: Critical nitrogen models; phosphorus dilution models; irrigation; maize; Nebraska.

Received for publication: 11 March 2017.

Revision received: 5 July 2017.

Accepted for publication: 5 July 2017.

CCopyright K. Djaman and S. Irmak, 2018

Licensee PAGEPress, Italy

Italian Journal of Agronomy 2018; 13:958

doi:10.4081/ija.2017.958

This article is distributed under the terms of the Creative Commons Attribution Noncommercial License (by-nc 4.0) which permits any noncommercial use, distribution, and reproduction in any medium, provided the original author(s) and source are credited.
}

\section{Introduction}

Increased crop productivity is usually associated with increased water and nutrient use efficiency. A balance needs to be established to optimise nutrient use in conjunction with efficient water use in order to protect the requisite environmental services and functions. Furthermore, optimisation of the use of resources (water and nitrogen) can be used to minimise pollution of the environment. Determination of within-season critical nutrient concentration under various irrigation management strategies can help to monitor the nutrient needs of crops and maintain such balance. The concentration of nitrogen $(\mathrm{N})$ in many crops is known to decrease with the increase in plant biomass (Greenwood et al., 1990; Lemaire and Gastal, 1997; Sheehy et al., 1998; Van Oosterom et al., 2001; Djaman et al., 2013).

The minimum $\mathrm{N}$ concentration necessary to achieve maximum aboveground biomass at any time during the growing season is defined as the critical $\mathrm{N}$ concentration (Ncrit) (Lemaire and Salette, 1984). The critical N dilution curve based on plant total biomass $\mathrm{N}$ concentration as developed by Lemaire and Salette (1984) is represented by an allometric function: $\mathrm{Nc}=a W^{-b}$ where, $W$ is the total shoot biomass [Mg dry matter (DM) ha $\left.{ }^{-1}\right]$, $\mathrm{Nc}$ is the total $\mathrm{N}$ concentration in shoot $\left(\mathrm{g} \mathrm{kg}^{-1} \mathrm{DM}\right)$, and $a$ and $b$ are estimated parameters. The parameter $a$ represents the $\mathrm{N}$ concentration in the total shoot biomass for $1 \mathrm{Mg} \mathrm{DM} \mathrm{ha}^{-1}$, and the parameter $b$ represents the coefficient of dilution describing the relationship between $\mathrm{N}$ concentration and shoot biomass. The concept of a critical $\mathrm{N}$ dilution curve based on plant total biomass $\mathrm{N}$ concentration was initially developed by Lemaire and Salette (1984) for tall fescue grass. While some investigators have reported variations in the critical $\mathrm{N}$ curve between regions, species, and even genotypes within species, the critical $\mathrm{N}$ model developed by Plénet and Lemaire (2000) for maize production is widely recognized in the literature as the reference curve for maize (Bélanger et al., 2001; Tei et al., 2002; Flénet et al., 2006; Xue et al., 2007; Ziadi et al., 2008). An inherent interaction would arise from variations in soil $\mathrm{N}$ supply, as related to profile $\mathrm{NO}_{3}$ - levels in arid or semi-arid regions or potential mineralisation under more humid or irrigated conditions (Lemaire et al., 2008; Lemaire and Gastal, 2009; Naud et al., 2009). The use of the $\mathrm{N}$ nutrition index (NNI) has been proposed as a plant-based approach for assessing crop $\mathrm{N}$ nutrition (Lemaire et al., 2008). The NNI is the ratio between actual biomass $\mathrm{N}$ concentration and predicted critical $\mathrm{N}$ concentration $\mathrm{N}_{\mathrm{c}}$ during the growing season (Lemaire et al., 1989; Justes et al., 1994). Dordas (2011) reported yields of linseed (Livia, Lirina, Creola) dependence on an N supply, which can be diagnosed using NNI. Ziadi et al. (2008, 2009) reported the reliability of using NNI for $\mathrm{N}$ fertiliser management under maize production, and recommended the use of $\mathrm{N}$ concentration of maize uppermost collared leaf at, or near, the V12 stage 
of development of maize. Leaf $\mathrm{N}$ concentration showed good correlation with NNI in maize with $\mathrm{R}^{2}=0.82$ (Ziadi et al., 2009) and grasslands with $\mathrm{R}^{2}=0.87$ (Duru, 2004). Yue et al. (2012) used the critical $\mathrm{N}$ dilution curve to validate NNI for optimising N management for winter wheat production while Li et al. (2012) indicated that NNI is a reliable indicator of optimal $\mathrm{N}$ management for maize production. However, NNI is not much useful in practice at farm level because it is plant destructive method that involves time-consuming measurements and destructive plant sampling (Prost and Jeuffroy, 2007) and does not suggest any recommendation in term of nitrogen fertiliser amount to address $\mathrm{N}$ deficiency in plants (Ziadi et al., 2008).

Diagnosis of $\mathrm{P}$ nutrition based on the relationship between $\mathrm{P}$ and $\mathrm{N}$ concentrations during plant growth was proposed for perennial grasses by Salette and Huché (1991) and Duru and Ducrocq (1997). Djaman et al. (2013) reported a positive relationship between maize $\mathrm{P}$ and $\mathrm{N}$ concentrations. Similar to Ncrit, plant critical phosphorus concentration (Pcrit) in shoot biomass has been determined for phosphorus diagnosis in plants for efficient nutrient management practices (Ulrich and Berry, 1961, Salette and Huché, 1991; Duru and Ducrocq, 1997; Bélanger and Richards, 1999; Bélanger and Ziadi, 2008). While most studies address the utilisation of NNI (Zaidi et al., 2008, 2009; Yue et al., 2012; Li et al., 2012) and N-P (Kamprath, 1987; Bélanger et al., 2011; Djaman et al., 2012) relationships as a management strategy in fully-irrigated settings, the relevant management tools were not developed and evaluated for crop nutrient management under limited irrigation and rainfed conditions. The application of the fertiliser recommendations that were developed for fully-irrigated settings may not be effective or even environmentally sustainable (e.g., greater leaching potential due to excessive fertiliser applications) under limited irrigation or rainfed settings (Djaman et al., 2013). Therefore, studies to understand plant nutrient status for better $\mathrm{N}$ and $\mathrm{P}$ fertiliser management practices using fertiliser recommendations developed under fully irrigated conditions for limited irrigation and rainfed conditions are needed to aid crop producers in increasing nutrient use efficiency and protecting the quality of soil and water resources. The objective of this study was to evaluate the critical $\mathrm{N}$ and $\mathrm{P}$ models developed under fully irrigated maize for $\mathrm{N}$ and $\mathrm{P}$ status in limited irrigated and rainfed maize settings in south central Nebraska.

\section{Materials and methods}

\section{Site description, experimental design, and general soil and crop management practices}

Field experiments were conducted at Clay Center, Nebraska (latitude $40^{\circ} 43^{\prime} \mathrm{N}$ and longitude $98^{\circ} 08^{\prime} \mathrm{W}$ at an elevation of $552 \mathrm{~m}$ above mean sea level) during the 2009 and 2010 growing seasons. The soil is a Hastings silt loam (fine, montmorillonitic, mesic Udic Argiustoll), a well-drained upland soil with topsoil field capacity of $0.34 \mathrm{~m}^{3} \mathrm{~m}^{-3}$, permanent wilting point of $0.14 \mathrm{~m}^{3} \mathrm{~m}^{-3}$ and a saturation point of $0.53 \mathrm{~m}^{3} \mathrm{~m}^{-3}$. The total available water holding capacity of the maize root zone $(0-1.20 \mathrm{~m})$ is approximately $240 \mathrm{~mm}$. The par-

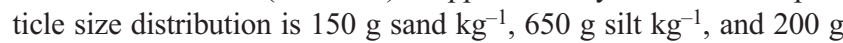
clay $\mathrm{kg}^{-1}$ with $25 \mathrm{~g}$ organic matter $\mathrm{kg}^{-1}$ in the topsoil $(0-0.30 \mathrm{~m})(\mathrm{Gee}$ Or, 2002; Rayment and Lyons, 2011; Irmak et al., 2008; Irmak, 2010). The experimental field (16 ha) was irrigated using a four-span hydraulic and continuous-move center-pivot irrigation system (T-L Irrigation Co., Hastings, Neb.) and was ridge-tilled in both years. The same maize hybrid Mycogen 2 V732 was planted on April 23, 2009, emerged on May 4-6 and was harvested on October 15, and was planted on April 28, emerged on May 15 (late emergence due to wet conditions in late April through mid-May) and was harvested on October 7, 2010. In both years, the planting population density was 73,000 plants $\mathrm{ha}^{-1}$ and the planting depth was $0.05 \mathrm{~m}$ with $0.76-\mathrm{m}$ row spacing in a north-south direction. Herbicide, insecticide, and fungicide were uniformly applied to the entire field as needed. Four irrigation treatments were imposed: fully-irrigated treatment (FIT), $75 \%$ FIT, $60 \%$ FIT, 50\% FIT and rainfed. The experimental design was completely randomised with three replications. Each replication plot was about 1 ha in size and the same plots were used in both years under the same irrigation regimes. The irrigation timings were based on the soil water content of the fully-irrigated treatment (FIT) such that a total of approximately $25 \mathrm{~mm}$ of irrigation was applied to the FIT each time the soil water in the root zone in the FIT reference plot was depleted by about $40 \%$ of the total available water (TAW). Thus, at each irrigation event, about 25, 19, 15 and $13 \mathrm{~mm}$ of irrigation water was applied to the FIT, $75 \%$ FIT, $60 \%$ FIT and $50 \%$ FIT treatments, respectively. Seven irrigations were applied during the 2009 growing season, i.e., July 8, July 14, July 21, August 4, August 11, August 19 and August 27. There were five irrigations

Table 1. Average weather conditions during the 2009 and 2010 maize growing seasons at the research site in south central Nebraska.

\begin{tabular}{|c|c|c|c|c|c|c|c|c|c|c|}
\hline Year & Month & $\underset{\left({ }^{\circ} \mathrm{C}\right)}{\mathrm{Tmax}}$ & $\begin{array}{l}\operatorname{Tmin} \\
\left({ }^{\circ} \mathrm{C}\right)\end{array}$ & $\begin{array}{l}\text { Tmean } \\
\left({ }^{\circ} \mathrm{C}\right)\end{array}$ & $\begin{array}{l}\text { RHmax } \\
(\%)\end{array}$ & $\underset{(\%)}{\text { RHmin }}$ & $\begin{array}{c}\text { RHmean } \\
(\%)\end{array}$ & $\begin{array}{l}\text { Wind speed } \\
\left(\mathrm{m} \mathrm{s}^{-1}\right)\end{array}$ & $\begin{array}{l}\text { Rainfall } \\
\text { (mm) }\end{array}$ & $\begin{array}{c}\text { Solar radiation } \\
\left(\mathrm{W} \mathrm{m} \mathrm{m}^{-2}\right)\end{array}$ \\
\hline \multirow[t]{10}{*}{2009} & April & 15.7 & 2.7 & 9.2 & 91.2 & 43.1 & 67.2 & 5.4 & 83.7 & 207.6 \\
\hline & May & 22.1 & 9.7 & 15.9 & 91.9 & 46.1 & 69 & 3.9 & 32.5 & 241.9 \\
\hline & June & 25.8 & 15.5 & 20.6 & 95.4 & 57.4 & 76.4 & 2.8 & 137.1 & 209 \\
\hline & July & 28.1 & 15.6 & 21.9 & 97.4 & 49.4 & 73.4 & 2.8 & 51.5 & 260.4 \\
\hline & August & 28 & 15.3 & 21.6 & 93 & 47.5 & 70.3 & 3.5 & 100.1 & 242.7 \\
\hline & September & 23.3 & 10.9 & 17.1 & 94.5 & 50.2 & 72.3 & 2.8 & 46.1 & 159.3 \\
\hline & October & 12.1 & 2 & 7.1 & 96.9 & 61.2 & 79 & 4.3 & 87.1 & 98.2 \\
\hline & April & 18.4 & 5.6 & 12 & 90 & 45.6 & 67.8 & 4.8 & 69.8 & 202.4 \\
\hline & May & 19.5 & 9.2 & 14.4 & 93.1 & 57.8 & 75.5 & 4.2 & 125.7 & 223.9 \\
\hline & June & 28.1 & 16.7 & 22.4 & 93.6 & 55.4 & 74.5 & 3.3 & 230.9 & 264.8 \\
\hline \multirow[t]{4}{*}{2010} & July & 30.1 & 19.1 & 24.6 & 94.7 & 54.1 & 74.4 & 3.1 & 57.4 & 245.4 \\
\hline & August & 31.5 & 18.2 & 24.8 & 93.1 & 45 & 69.1 & 3.3 & 89.2 & 248 \\
\hline & September & 25.9 & 11.6 & 18.7 & 93.8 & 47.2 & 70.5 & 3.6 & 56.9 & 174.4 \\
\hline & October & 22.4 & 6 & 14.2 & 86.2 & 33 & 59.6 & 3.4 & 5.8 & 157.4 \\
\hline
\end{tabular}

Tmax, maximum temperature; Tmin, minimum temperature; RHmax, maximum relative humidity. 
during the 2010 growing season, i.e., July 21, July 29, August 5, August 12 and August 19 (Table 1). A uniform N rate was applied based on the average soil residual $\mathrm{N}$ from the previous year before planting and yield targets regardless the irrigation treatment. In 2009 , a total of $197 \mathrm{~kg} \mathrm{ha}^{-1}$ of $\mathrm{N}$ and $22.3 \mathrm{~kg} \mathrm{ha}^{-1}$ of P were applied (broadcast) as 28-0-0 and 10-34-0. In 2010, a total of $243 \mathrm{~kg} \mathrm{ha}^{-1}$ of $\mathrm{N}$ and $80 \mathrm{~kg} \mathrm{ha}^{-1}$ of $\mathrm{P}$ were applied in 11-52-0, 28-0-0 and 10-34-0.

\section{Measurement of soil water status and plant sampling}

Soil water status was monitored using two methods. Watermark Granular Matrix sensors (WGMs, Irrometer, Co., Riverside, CA) were used to monitor soil matric potential (SMP) on an hourly basis. The WGMs are an indirect method of measuring SMP by directly measuring soil water tension. SMP measurements were converted to soil water content in percent volume using a soil-water retention curve pre-determined for the Hastings silt loam soil at the study field by Irmak (2010) (Equation 1).

$\theta_{v}=3 * 10^{-6 *} \psi^{2}-0.0013 * \psi+0.3764$

where, $\theta_{\mathrm{v}}$ is the volumetric soil water content $\left(\mathrm{m}^{3} \mathrm{~m}^{-3}\right)$ and $\psi$ is the soil matric potential $(\mathrm{kPa})$.

The effective rooting depth for maize in the experimental site is $1.20 \mathrm{~m}$ (Djaman and Irmak, 2012; Rudnick and Irmak, 2014), thus the WGMs were installed every $0.30 \mathrm{~m}$ down to $1.20 \mathrm{~m}$ soil profile. The sensors were installed to monitor soil water in two of the three replications of each treatment. The sensors were installed in the plant row (each sensor was located midway between two maize plants). The sensors were connected to a Watermark Monitor datalogger (Irrometer Co., Riverside, CA) and measurements were recorded throughout the growing season. In addition to WGMs, soil water status was also measured once or twice a week throughout both growing seasons using a model 4302 neutron attenuation meter (Troxler Electronics Laboratories, Inc., NC, USA) at $0.30-\mathrm{m}$ increments to a depth of $1.80 \mathrm{~m}$. Neutron probe access tubes were installed between the two maize plants in the plant row of representative experimental units of each treatment. The neutron probe measurement data were controlled using the manufacturer's and site calibration curves and were used to ascertain the temporal trend in soil moisture content under each treatment. Irrigation timings were determined based on the WGMSs installed in the FIT. Under the FIT, the TAW in the top $1.20 \mathrm{~m}$ profile was kept between approximately $90 \%$ of field capacity and
$55 \%$ of total available water. The depletion criterion of $40 \%$ to $45 \%$ TAW was adopted to prevent water stress under the FIT, as the center pivot requires about three days to make a complete revolution.

Prior to planting, soil samples were taken in $0.30-\mathrm{m}$ increments to a depth of $1.50 \mathrm{~m}$ for $\mathrm{N}, \mathrm{P}$, and $\mathrm{K}$ analysis for determining fertiliser application rates. From emergence to physiological maturity, six plants from two replications of each treatment were selected randomly to determine biomass production over time. The aboveground biomass was taken on seven sampling dates (10 June, 2 July, 21 July, 3 August, 14 August, 3 September, and 24 October) in 2009 and five sampling dates (6 July, 19, July, 13 August, 3 September, and 27 September) in 2010 , and dried at $70^{\circ} \mathrm{C}$ until they reached a constant weight. At physiological maturity, the aboveground portions of 6 plant samples were harvested from each replication of each treatment and separated into leaves, stover and grain. The plant and grain samples were weighed and frozen before being sent to the laboratory for $\mathrm{N}$ and $\mathrm{P}$ analysis. Biomass and grain $\mathrm{N}$ and $\mathrm{P}$ concentrations are expressed in percent on a dry weight basis, and the soil $\mathrm{N}$ and $\mathrm{P}$ concentrations are expressed in $\mathrm{mg} \mathrm{kg}^{-1}$. Nutrient ( $\mathrm{N}$ and $\mathrm{P}$ ) uptake in grain was calculated by multiplying grain yield by grain nutrient concentration. At maturity, two center rows (15 $\mathrm{m}$ long by 8-row wide) of each replication were hand-harvested to determine the grain yield of each treatment. The grain yield was determined from the hand-shelled ears and was adjusted to $155 \mathrm{~g} \mathrm{~kg}^{-1}$ grain moisture content for analyses.

\section{Critical nitrogen dilution model and nitrogen nutrition index}

The critical nitrogen dilution model developed by Plénet and Lemaire (2000) was used to evaluate the nitrogen concentration in maize shoot biomass under different irrigation regimes. The nitrogen nutrition index (NNI) of maize crop at each sampling date was determined by dividing $\mathrm{N}$ concentration of the shoot biomass by the critical N concentration (Ncrit) (Lemaire et al., 2008; Plénet and Lemaire, 2000; Lemaire and Gastal, 1997, 2009). Critical N concentration for maize (in $\mathrm{g} \mathrm{kg}^{-1}$ ), i.e., the minimum $\mathrm{N}$ concentration required achieving maximum shoot growth, defined as a function of shoot biomass (Plénet and Lemaire, 2000) is:

$$
\text { Ncrit }=34.0 \times \mathrm{W}^{-0.37}
$$

where, $\mathrm{W}$ is the total shoot biomass expressed in $\mathrm{Mg} \mathrm{ha}^{-1}$ dry matter.

Table 2. Evolution of the above ground biomass of maize under the different irrigation regimes during the 2009 and 2010 growing seasons.

\begin{tabular}{|c|c|c|c|c|c|c|}
\hline \multirow[t]{2}{*}{ Year } & \multirow[t]{2}{*}{ DAP } & \multicolumn{5}{|c|}{ Aboveground biomass $\left(\mathrm{Mg} \mathrm{ha}^{-1}\right)^{*}$} \\
\hline & & Rainfed & $50 \%$ FIT & $60 \%$ FIT & $75 \%$ FIT & FIT \\
\hline \multirow[t]{9}{*}{2009} & 49 & $0.91^{\mathrm{a}}$ & $0.89^{\mathrm{a}}$ & $0.89^{\mathrm{a}}$ & $1.03^{\mathrm{a}}$ & $0.93^{\mathrm{a}}$ \\
\hline & 61 & $4.85^{\mathrm{a}}$ & $4.69^{\mathrm{a}}$ & $5.59^{\mathrm{a}}$ & $5.48^{\mathrm{a}}$ & $5.26^{\mathrm{a}}$ \\
\hline & 71 & $6.48^{\mathrm{a}}$ & $6.98 \mathrm{a}$ & $6.45^{\mathrm{a}}$ & $6.66^{\mathrm{a}}$ & $6.31^{\mathrm{a}}$ \\
\hline & 92 & $12.65^{\mathrm{b}}$ & $13.92^{\mathrm{a}}$ & $14.07^{\mathrm{a}}$ & $12.25^{b}$ & $14.24^{\mathrm{a}}$ \\
\hline & 103 & $15.55^{\mathrm{b}}$ & $16.05^{b}$ & $18.52^{\mathrm{a}}$ & $17.69^{\mathrm{a}}$ & $16.03^{b}$ \\
\hline & 114 & $15.55^{\mathrm{b}}$ & $18.85^{\mathrm{a}}$ & $18.77^{\mathrm{a}}$ & $18.15^{\mathrm{a}}$ & $19.76^{\mathrm{a}}$ \\
\hline & 135 & $15.55^{\mathrm{c}}$ & $19.01^{\mathrm{b}}$ & $18.92^{\mathrm{b}}$ & $19.36^{\mathrm{b}}$ & $22.32^{\mathrm{a}}$ \\
\hline & 70 & $6.14^{\mathrm{a}}$ & $6.39^{\mathrm{a}}$ & $6.12^{\mathrm{a}}$ & $5.90^{\mathrm{a}}$ & $4.75^{\mathrm{a}}$ \\
\hline & 83 & $7.15^{\mathrm{a}}$ & $7.75^{\mathrm{a}}$ & $7.90^{\mathrm{a}}$ & $7.12^{\mathrm{a}}$ & $6.39^{a}$ \\
\hline \multirow[t]{4}{*}{2010} & 108 & $8.48^{\mathrm{a}}$ & $8.84^{\mathrm{a}}$ & $9.83^{\mathrm{a}}$ & $8.74^{\mathrm{a}}$ & $8.84^{\mathrm{a}}$ \\
\hline & 129 & $16.83^{c}$ & $18.51^{\mathrm{b}}$ & $17.35^{\mathrm{bc}}$ & $19.62^{\mathrm{ab}}$ & $21.34^{\mathrm{a}}$ \\
\hline & 147 & $20.84^{c}$ & $24.02^{\mathrm{b}}$ & $24.57^{\mathrm{b}}$ & $25.05^{\mathrm{b}}$ & $27.24^{\mathrm{a}}$ \\
\hline & 153 & $23.86^{\mathrm{c}}$ & $24.92^{\mathrm{b}}$ & $25.02^{\mathrm{b}}$ & $27.04^{\mathrm{ab}}$ & $28.62^{\mathrm{a}}$ \\
\hline
\end{tabular}

\footnotetext{
*Aboveground biomass values followed by the same letter on the same line within a year are not significantly different at the $10 \%$ significance level. DAP, days after planting; FIT, fully-irrigated treatment.
} 


\section{Critical phosphorus dilution model}

The $\mathrm{P}$ concentration in relation to $\mathrm{N}$ under non-limiting $\mathrm{N}$ conditions described by the linear relationship developed by Ziadi et al. (2007) is:

Pcrit $=1.00+0.094 \times \mathrm{N}$

in which the concentrations are expressed in $\mathrm{g} \mathrm{kg}^{-1}$ dry matter. This relationship approximates the critical P concentration (Pcrit) under non-limiting $\mathrm{N}$ conditions, i.e., the minimum $\mathrm{P}$ concentration needed to achieve maximum shoot growth assuming that soil $\mathrm{P}$ availability does not limit shoot growth. In addition, the relationship between shoot biomass $\mathrm{N}$ and $\mathrm{P}$ obtained in this study was used in combination with the critical nitrogen model (Pcrit and Ncrit) for comparison and the acronym Pcrit-Ncrit was used for the new critical $\mathrm{P}$ function derived from the critical $\mathrm{N}$ :

Pcrit-Ncrit $=1.00+0.094\left(34.0 \mathrm{x} \mathrm{W}^{-0.37}\right)$

Similar to NNI, phosphorus nutrition index (PNI) was calculated to analyse the effect of limited irrigation on maize plant nutrition. The PNI for maize at each sampling date was determined by dividing $\mathrm{P}$ concentration of the shoot biomass by the critical P concentration.

The relative yield was calculated as the ratio of the grain yield under a given irrigation regime to the highest grain yield obtained under the fully irrigation treatment. The relative yield was expressed as a function of NNI, and a linear-plateau function was fitted.

\section{Statistical analysis}

The aboveground biomass data for each sampling date for the two growing seasons were subjected to analysis of variance (ANOVA) procedure of the Statistical Analysis System (SAS Institute Inc., 2003. SAS Online Doc ${ }^{\circledR}$ 9.1., Cary, NC, USA). The regression procedure was used to perform stepwise multiple regression analysis and the means were separated using Fisher's protected least significance difference (LSD) test at the $90 \%$ level of probability for the aboveground biomass and at the $95 \%$ level for nutrient concentration in the biomass. The relationships between measured $\mathrm{N}$ and $\mathrm{P}$ concentrations in the aboveground biomass and the accumulated aboveground biomass under different irrigation treatments were determined by an allometric function based on power regression.

\section{Results and discussion}

\section{Relationship between nitrogen and phosphorus concen- trations in maize shoot biomass}

Irrigation regimes significantly impacted the above ground biomass production from 92 DAP in 2009 and from 129 DAP in 2010 to crop maturity (Table 2 ). Due to early rainfall shortage in 2009, limited irrigation application at reproductive and grain filling stages impacted the aboveground biomass in 2009 than in 2010. Maize aboveground biomass shoot concentration in nitrogen as function of irrigation regimes had linearly relationship with the shoot phosphorus concentration with coefficient of determination $\left(\mathrm{R}^{2}\right)$ ranging from 0.84 to 0.88 (Figure 1). The slopes of these relationships were $0.082,0.073,0.082,0.078$ and 0.750 under rainfed, $50 \%$ FIT, 60\% FIT, 75\% FIT and FIT, respectively. The positive relationship observed between $\mathrm{P}$ and $\mathrm{N}$ concentrations does reflect a parallel decline due to increasing biomass, but also the more fundamental interaction of these elements in plant nutrition. The irrigation regimes did not significantly affect the slopes of these relationships $(p=0.21)$. The $\mathrm{P}$ concentration in relation to $\mathrm{N}$ in maize under non-limiting $\mathrm{N}$ conditions was described by the linear relationship developed by Ziadi et al. (2007), Greenwood et al. (2008), Bélanger et al. (2011) and Ciampitti et al. (2013). Bélanger et al. (2011) reported linear-plateau relationships between maize and wheat leaf $\mathrm{N}$ and $\mathrm{P}$ concentrations considering the growing season and linear relationships when considering stem elongation for wheat and silking for maize. Maize shoot biomass $\mathrm{P}$ was also strongly linearly correlated to shoot biomass $\mathrm{N}$ as reported by Kamprath (1987). Ziadi et al. (2007) indicated that the decline in $\mathrm{P}$ and $\mathrm{N}$ concentrations during biomass accumulation, both of which relate to nutrient dilution, appeared to be of a general nature and could be applied to several crop species. Both $\mathrm{P}$ and $\mathrm{N}$ concentrations in grasses decrease with increasing shoot biomass and advancing maturity (Bélanger and Richards, 1997, 1999); and because of similar decreases in $\mathrm{N}$ and $\mathrm{P}$ concentration with increasing shoot biomass, the relationship between $\mathrm{P}$ and $\mathrm{N}$ concentrations could be used to determine P status.

\section{Evaluation of critical nitrogen model and nitrogen nutrition index}

The irrigation regimes impacted shoot biomass $\mathrm{N}$ concentration (Figure 2). The points with $\mathrm{N}$ concentrations below the critical $\mathrm{N}$ dilution curve represent $\mathrm{N}$ deficiency conditions and points above the critical $\mathrm{N}$ dilution curve represent luxury $\mathrm{N}$ uptake or excessive $\mathrm{N}$ supply while those close to the curve represent sufficient $\mathrm{N}$ conditions for optimum crop growth. Shoot biomass nitrogen concentration stayed above the Ncrit throughout the growing season under FIT and it was close to 1 under $75 \%$ FIT from about 83 DAP to crop physiological maturity. NNI varied from 0.68 for the rainfed treatment to 2.0 for the $75 \%$ FIT. $N$ content in biomass was below Ncrit and NNI was below 1.0 from 105 DAP (tasseling) to harvest under rainfed and 50\% FIT and from 114 DAP (silkinggrain fill stage) to harvest under $60 \%$ FIT (Figure 3). NNI was higher earlier in the season and decreased with time due to interspecific and intra-specific competition for soil N (Jensen, 1996;

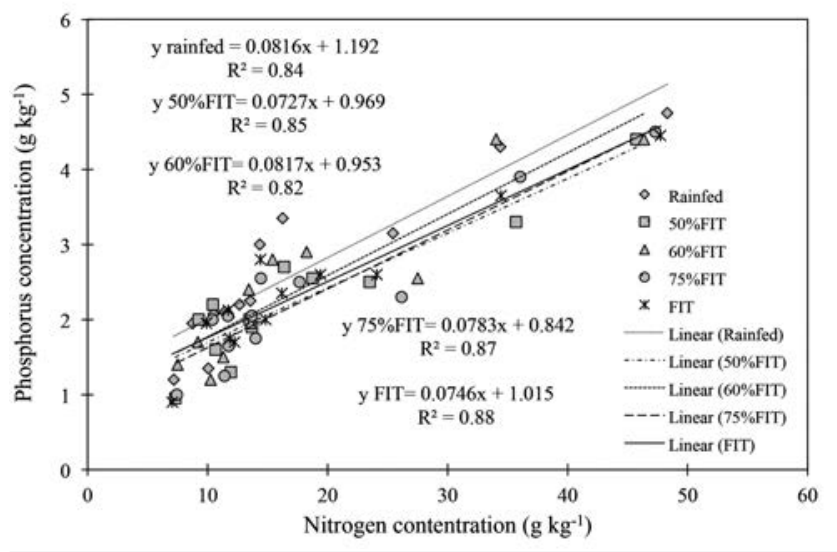

Figure 1. Relationship between maize phosphorus and nitrogen concentrations under fully-irrigated treatment (FIT), $75 \%$ FIT, 60\% FIT, 50\% FIT, and rainfed conditions in 2009 and 2010. 
Corre-Hellou et al., 2006; Bedoussac and Justes, 2009; Lindquist et al., 2010). This showed that crops were under non-limiting nitrogen supply conditions during their vegetative stage up to flowering stage under all irrigation regimes. Parameter $a$, which represents percent plant $\mathrm{N}$ concentration when crop mass is $1 \mathrm{Mg}$ $\mathrm{ha}^{-1}$ dry matter, was equal to $56.7,52.9,55.9,57.2$, and 55.1 under rainfed, $50 \%, 60 \%, 75 \%$ and $100 \%$ FIT, respectively, with no dif- ference relative to irrigation regime. Parameter $b$, which represents the dilution coefficient, varied from 0.51 under FIT to 0.58 under rainfed conditions. Although the dilution coefficient increased with decreasing irrigation application rate, all three limited irrigation regimes had similar dilution coefficients higher than the FIT. The rainfed treatment had the lowest dilution coefficient due to the reduced aboveground biomass accumulation shown in Table 2 .
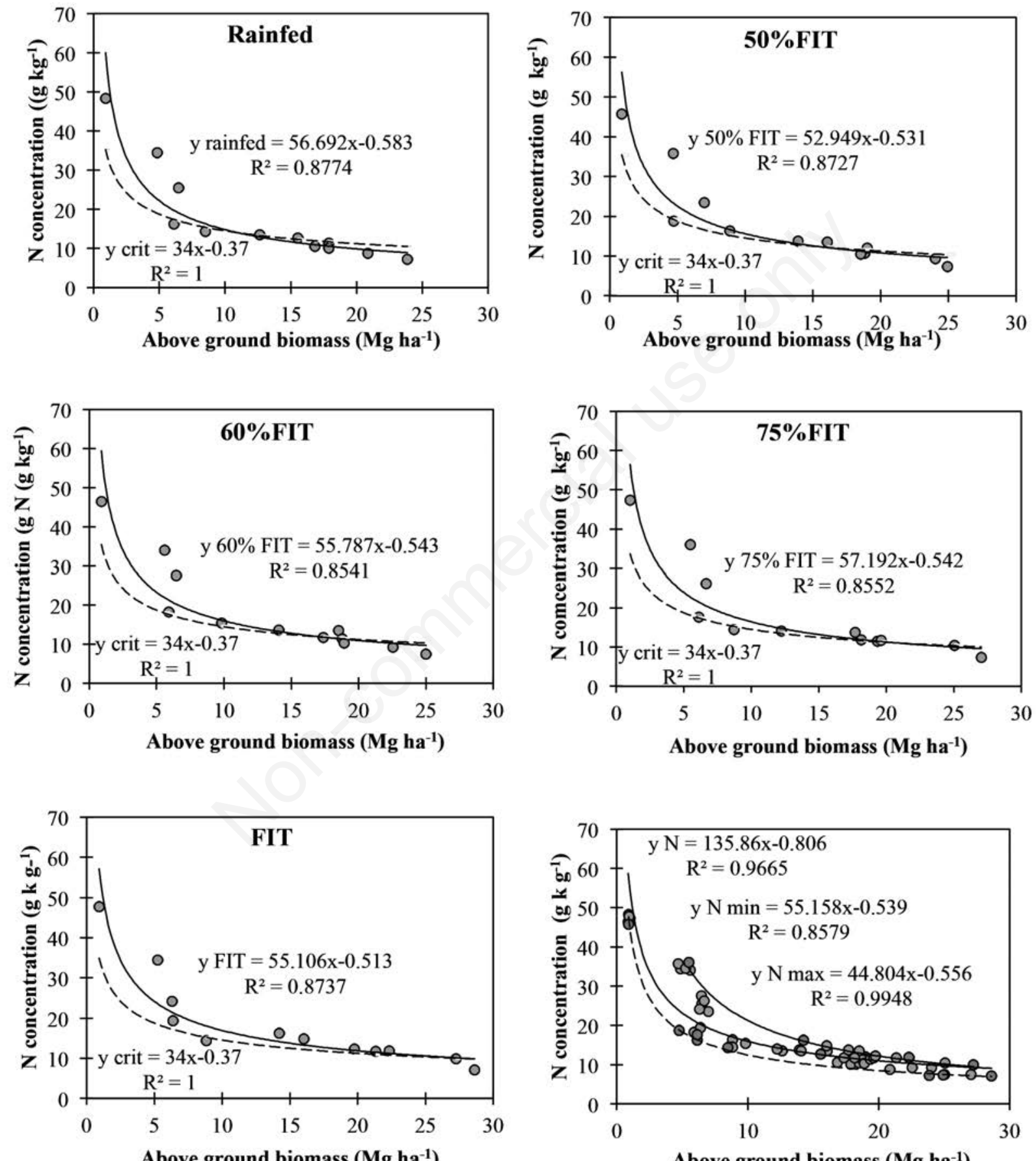

Above ground biomass $\left(\mathrm{Mg} \mathrm{ha}^{-1}\right)$

Figure 2. Comparison of the nitrogen $(\mathrm{N})$ dilution curves (continuous line) to the critical nitrogen dilution curve (ycrit) (dashed line) under rainfed, $50 \%$ fully-irrigated treatment (FIT), $60 \%$ FIT, 75\% FIT, and FIT conditions and the pooled irrigation treatments with maximum (Max) and minimum (Min) nitrogen dilution curves. 
Increasing biomass had a dilution effect on $\mathrm{N}$ concentration. The inverse relationship between the dilution coefficient and the irrigation regime is, therefore, due to biomass production relative to irrigation regime as the biomass accumulation increased with irrigation. Overall, both FIT and 75\% FIT had NNI close to 1.0 from 83 DAP in both year, the $60 \%$ FIT, $50 \%$ FIT and the rainfed treatments sowed NNI values less than 1 from about 108 DAP toward the end of the growing season.

Critical nutrient concentrations separate nutrient deficiency from nutrient sufficiency, but they vary with plant parts, physiological age, and environmental factors (Munson and Nelson, 1990; Westfall et al., 1990; Herrmann and Taube, 2004; Rashid et al., 2005). The onset of $\mathrm{N}$ deficiency occurred in mid-August (108 DAP) under limited irrigation and rainfed treatments when the crops reached the grain-filling stage (Figure 4). Moisture stress would have limited $\mathrm{N}$ transport through mass flow or diffusion. Similarly, Gonzalez-Dugo et al. (2010) showed after Onillon et al. (1995) that tall fescue grass had lower NNI under nitrogen deficiency and or limited irrigation or rainfed conditions. Factors such as the rate of $\mathrm{N}$ deposition, mineralisation, mass flow and diffusion in the soil (Nye and Tinker, 1977), determine the availability of $\mathrm{N}$ at the root surface. Irrigation level and soil water availability also influence the mobility of nutrients in the soil - root system and uptake by crops. Decreases in irrigation levels probably decreased the availability and transport of nutrients, particularly $\mathrm{N}$ and $\mathrm{P}$. The results of this evaluation confirms the finding of Gonzalez-Dugo et al. (2010) who reported that in limited irrigated tall fescue plants $(0 \%, 30 \%$ and $80 \%$ of ET) $\mathrm{N}$ concentrations were lower than the critical $\mathrm{N}$ concentration that allow maximum crop growth. As the major transport agent, and given its central role in many physiological processes, such as mineral nutrition (Lemaire and Denoix, 1987), water availability determines the entire $N$ biogeochemical cycle and, ultimately, its availability for plant production (Ruffo et al., 2006). Nitrogen absorption by crops is automatically reduced under dry conditions, even when mineral $\mathrm{N}$ is present in the root zone (Foyer et al., 1998; Ferrario-Mery et al., 1998; GonzalezDugo et al., 2005; Xu et al., 2006; Robredo et al., 2011; Chen et al., 2015). Our research results support the findings of other researchers. Kumar and Dey (2011) reported positive affect of irrigation amount and method nutrient uptake by strawberry. Higher soil water availability increased N, P, and K uptake in Common Indian Rosewood (Dalbergia sissoo) (Singh and Singh, 2009). Water-limiting conditions decrease the mineralisation of organically bound nutrients (Walworth, 1992) and nutrient transport in the soil by mass flow and diffusion also decreases (Seiffert et al., 1995). Nutrient availability at the root surface decreases under water stress and is dependent on the intensity of the stress (Buljovcic and Engels, 2001). Therefore, limited irrigation affects nutrient uptake and the least uptake occurred in the rainfed treatment as reported by Hu et al. (2006 and 2009) and Li et al. (2007).

The NNI can be used as a within-season diagnosis tool to manage nitrogen fertilisation in relation to water availability and to analyse maize aboveground biomass productivity. It also has the potential to detect nitrogen deficiency as well as over-fertilisation. In-season fertigation fractioning could be used for optimum fertiliser use and to reduce environmental pollution from nitrate leaching into ground and surface water resources when coupled with proper irrigation management.

In-season $\mathrm{N}$ fertiliser diagnosis and timely applications should result in more efficient fertiliser use and reduced soil residual nitrate- $\mathrm{N}$ that increased with total water supply (Djaman et al., 2013) which was observed to result in leaching during winter time and early spring in locations where enough precipitation occurs to cause such conditions. Furthermore, pre-plant nitrogen must be adjusted to the yield target and late season supplied $\mathrm{N}$ must be adjusted to increase grain protein and nitrogen use efficiency and reduce the potential for off-season leaching losses. Gehl et al. (2005) reported that fertiliser $\mathrm{N}$ rates could be reduced for fine-textured (i.e., silt-loam) soils by an average of about $40 \%$ of the cur-

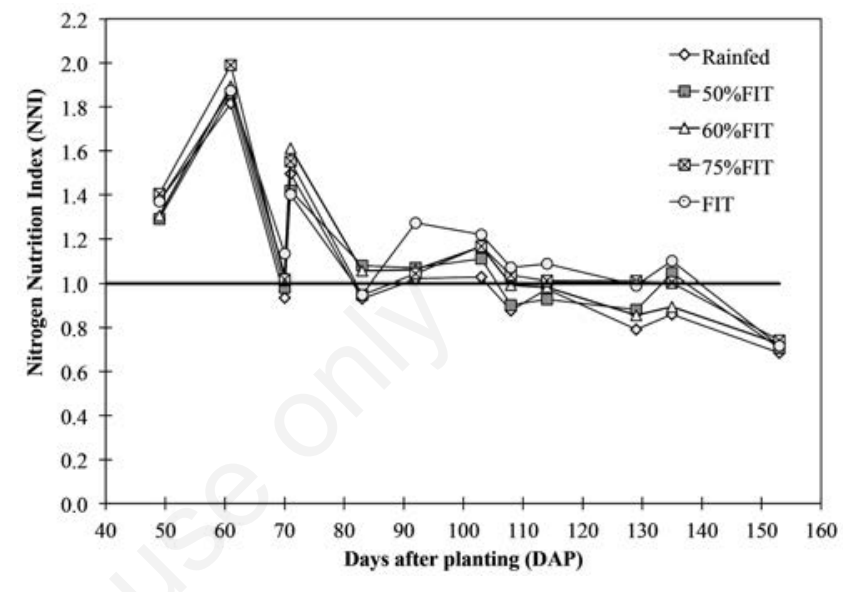

Figure 3. Distribution of nitrogen nutrition index (NNI) of maize under fully-irrigated treatment (FIT), 75\% FIT, 60\% FIT, 50\% FIT, and rainfed conditions during the growing season.
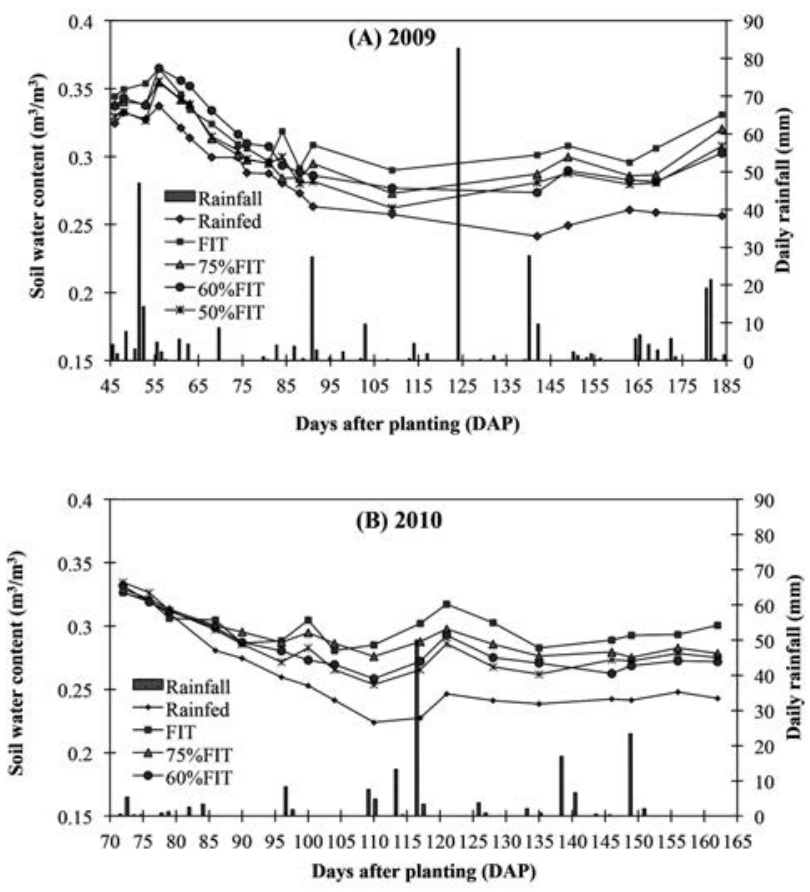

Figure 4. Seasonal evolution of maize root-zone average soil water content under fully-irrigated treatment (FIT), 75\% FIT, 60\% FIT, 50\% FIT, and rainfed conditions in 2009 (A) and 2010 (B) along with daily precipitation events. 
rent $\mathrm{N}$ recommendation when split applying $\mathrm{N}$. Thus, extension $\mathrm{N}$ recommendations are often excessive for Midwestern corn production (Lory and Scharf, 2003; Bender et al., 2013; Rosenstock et al., 2013). The environmental risk associated with irrigated maize production, specifically, $\mathrm{NO}_{3}$ leaching to groundwater, can in fact be minimised when $\mathrm{N}$ fertiliser and irrigation inputs do not exceed crop requirements and $\mathrm{N}$ fertiliser is applied to more closely match crop demand (in-season applications). Therefore, in this research two boundary curves were calculated using the observed maximum and minimum $\mathrm{N}$ concentrations (Nmax and $\mathrm{Nmin}$ ) on each sampling date as represented by the following equations:

$$
\begin{array}{lr}
\mathrm{Nmax}=55.16 \times \mathrm{W}^{-0.539} & \left(\mathrm{R}^{2}=0.86\right) \\
\mathrm{Nmin}=44.80 \times \mathrm{xW}^{-0.556} & \left(\mathrm{R}^{2}=0.99\right)
\end{array}
$$

The relationship between maize relative grain yield under limited irrigation and NNI is expressed by a linear-plateau model, which explained $36.3 \%$ of the variation (Li et al., 2012). Under FIT, 75\% FIT and 60\% FIT, seasonal average NNI values were higher than 0.9 and were related to constant relative yield of 0.95 . Under rainfed and $50 \%$ FIT treatments, $\mathrm{NNI}<0.9$, and relative yield was described by the linear function in equation (7) (Figure 5):

$$
\frac{\mathrm{Y}}{\mathrm{Ym}}=7.5 \mathrm{NNI}-5.77
$$

where, $\mathrm{Y}$ is the grain yield of rainfed or limited irrigation $(50 \%$ FIT) treatments and Ym is the grain yield of FIT. Y and Ym are expressed in $\mathrm{Mg} \mathrm{ha}^{-1}$; NNI is the in-season average NNI. The results indicated that the $\mathrm{N}-\mathrm{Crit}$ model of Plénet and Lemaire (2000) is a valid tool for within-season diagnosis of $\mathrm{N}$ in maize plants under full and limited irrigation and rainfed conditions. Similarly, Ziadi et al. (2008) found that the critical N curve from France is valid in eastern Canada and NNI calculated from that curve is a reliable indicator of the level of $\mathrm{N}$ stress during the maize growing season.

Plant-based diagnostic methods of $\mathrm{N}$ deficiency have been used to improve $\mathrm{N}$ management and decrease the risk of $\mathrm{N}$ loss to ground and surface waters (Lemaire et al., 2008; Ziadi et al., 2008). However, Barbieri et al. (2013) reported that the dilution curve proposed by Plénet and Lemaire (2000) was too high, implying the need for local calibration to account for genotypic, climatic, and soil variations that affect $\mathrm{N}$ availability or utilisation, or whenever the $\mathrm{N}$ fertiliser rate was insufficient. Similarly, the critical $\mathrm{N}$ dilution curve of Justes et al. (1994) for winter wheat production in France is widely recognised in the literature as a reference resource (Stockle and Debaeke, 1997; Jeuffroy and Recous, 1999) but was much higher than the critical $N$ dilution curve by Yue et al. (2012) and Chen and Zhu (2013) in China, Skonieski et al. (2012) in Brazil, and Tei et al. (2002) in Italy. Although the equation of Plénet and Lemaire (2000) is applicable under maize production in Nebraska, there is a need to develop critical nutrient curves for each nutrient under local agroecological conditions, basically with fertiliser adjustment to irrigation regimes and yield target.

\section{Evaluation of critical phosphorus model}

Phosphorus concentration in the shoot biomass decreased with biomass accumulation and varied from 4.8 to $1.0 \mathrm{~g} \mathrm{~kg}^{-1}$, with FIT having the highest $\mathrm{P}$ concentration. Although $\mathrm{P}$ concentration decreased with increasing irrigation regime, $\mathrm{P}$ concentrations between rainfed, 50\% FIT, 60\% FIT and 75\% FIT (Figure 6) were not significantly different. Critical P model evaluation showed that the maize plants experienced phosphorus deficiency under irrigated treatments (Figure 6) when P fertiliser was applied at the rate of $22.3 \mathrm{~kg} \mathrm{ha}^{-1}$ in 2009 and $80 \mathrm{~kg} \mathrm{ha}^{-1}$ in 2010 based on soil P concentration at planting, interpreted according to the University of Nebraska's fertiliser recommendations. Only rainfed maize plants received adequate $\mathrm{P}$ fertilisation (Figure 6). Two-year average $\mathrm{P}$ concentration in maize shoot at grain filling stage were 2.12, 1.94, $1.93,1.90$, and $2.03 \mathrm{~g} \mathrm{~kg}^{-1}$ under rainfed, $50 \%, 60 \%, 75 \%$ and $100 \%$ FIT, respectively. Smyth and Cravo (1990) observed that the aboveground biomass $\mathrm{P}$ concentration under broadcast of $0,11,22$, 44 , and $176 \mathrm{~kg} / \mathrm{ha}$ and banded of $0,11,22,44 \mathrm{~kg} \mathrm{P} / \mathrm{ha}$, was $1.6 \mathrm{~g}$ $\mathrm{kg}^{-1}$ higher than the critical foliar $\mathrm{P}$ concentration in maize. Chaudhary et al. (2003) reported that at about 75 DAP, the shoot biomass averaged about $10 \mathrm{Mg} \mathrm{ha}^{-1}$ with average $\mathrm{P}$ concentration varying from 2.4 to $3.1 \mathrm{~g} \mathrm{~kg}^{-1}$, which is higher than the critical phosphorus concentration values, ranging from 2.2 to $2.6 \mathrm{~g} \mathrm{~kg}^{-1}$ for 40-60 cm tall maize plants. Wortmann et al. (2009) reported maize stover $\mathrm{P}$ concentration of 0.5 to $2.9 \mathrm{~g} \mathrm{~kg}^{-1}$, depending on $\mathrm{P}$ fertiliser application rate. In Australia, Zia et al. (1988) indicated that $100 \%$ of relative yield was obtained at a P tissue level of $1.8 \mathrm{~g}$ $\mathrm{kg}^{-1}$ while the critical toxic value of $\mathrm{P}$ for maize growth was $3.6 \mathrm{~g}$ $\mathrm{kg}^{-1}$. Rashid and Iqbal (2012) reported that maize aboveground biomass $\mathrm{P}$ concentration of $2.3 \mathrm{~g} \mathrm{~kg}^{-1}$ is required to obtain $95 \%$ relative yield. Irrigation improved $P$ uptake and use efficiency in winter wheat (Yu et al., 2013), and in maize (Yaseen et al., 2014). Due to phosphorus fertiliser application method by broadcasting, the non-availability of $\mathrm{P}$ to maize plants might be caused by phosphorus loss through runoff (Shapiro et al., 2008). Morel et al. (1992) and Heckman et al. (2006) reported that soil analyses are poor predictors of crop $\mathrm{P}$ requirements under field conditions, primarily because the methods used do not account for the slow release of sorbed P (Steffens, 1994), and the mineralisation of soil organic P (Tiessen et al., 1994). In this research, P fertiliser was partly broadcast in 2010. Incorporating P into the soil results in more effective use and less potential for loss through run-off (Djaman et al., 2013).

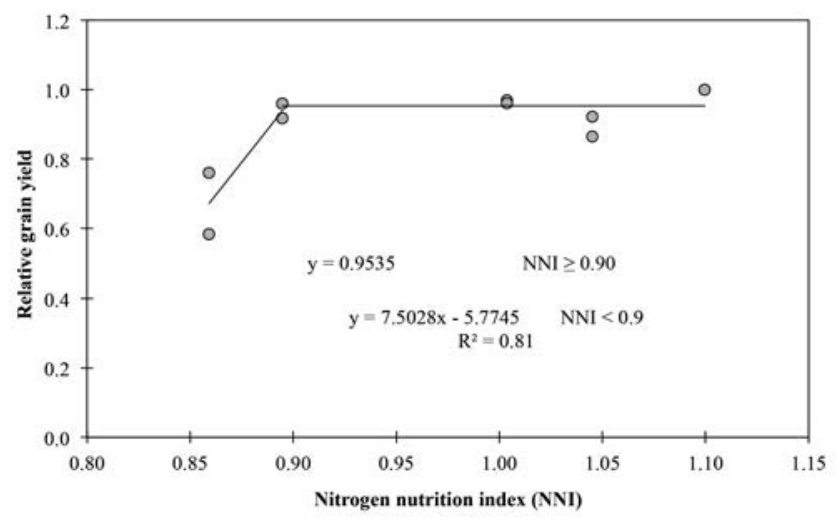

Figure 5. Relationship between relative grain yield and nitrogen nutrition index (NNI) near maize physiological maturity stage. 
Applying $\mathrm{P}$ fertiliser in bands is usually more efficient than broadcasting, especially when soil $\mathrm{P}$ is very low (Shapiro et al., 2003). Furthermore, current University of Nebraska fertiliser recommendations do not recommend $\mathrm{P}$ and $\mathrm{K}$ application for maize when Bray-1 $\mathrm{P}$ is greater than $0.015 \mathrm{~g} \mathrm{~kg}^{-1}$ and exchangeable $\mathrm{K}$ is greater than $0.124 \mathrm{~g} \mathrm{~kg}^{-1}$. These recommendations are mainly based on research conducted when mean maize grain yields in
Nebraska were less than $5 \mathrm{Mg} \mathrm{ha}^{-1}$ as compared with the 2008 average yields exceeding $10 \mathrm{Mg} \mathrm{ha}^{-1}$ (USDA-NASS, 2008) and with yields often exceeding $15 \mathrm{Mg} \mathrm{ha}^{-1}$. Whenever the critical $\mathrm{P}$ concentration model can be used to quantify the degree of $\mathrm{P}$ deficiency in maize during its growth and development stages, the evaluation of critical P derived from critical N model (Pcrit-Ncrit) showed that the results closely coincide with the results obtained
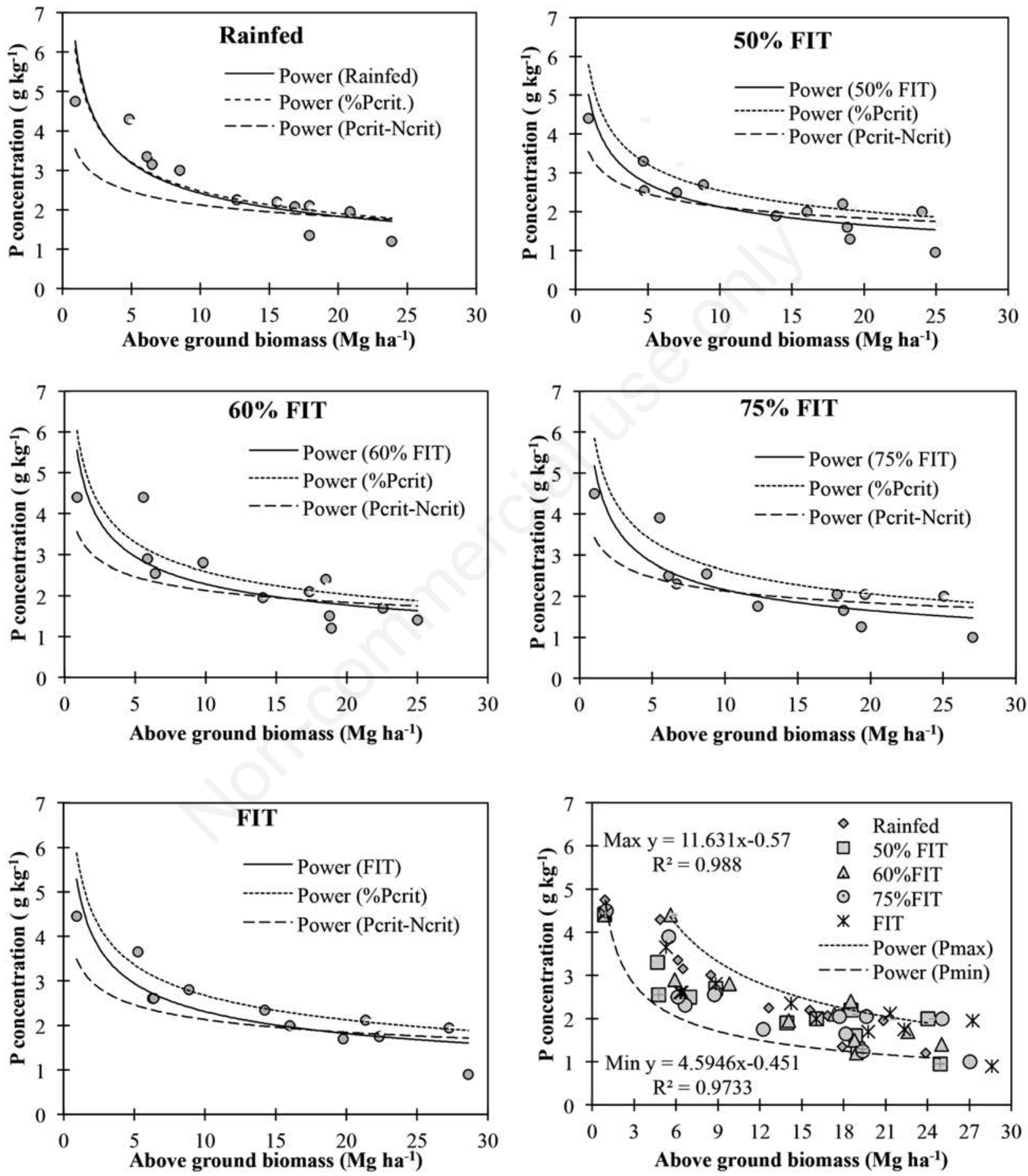

Figure 6. Evaluation of critical phosphorus concentration in maize aboveground shoot biomass under under rainfed, $50 \%$ fully-irrigated treatment (FIT), $60 \%$ FIT, 75\% FIT, FIT conditions using P-N relationship and critical P model and the Max and Min P content under irrigated and rainfed maize. P, phosphorus; Max, maximum; Min, minimum; Pcrit, critical phosphorus; Pcrit-Ncrit, critical phosphorus asssociated with critical nitrogen. 
for the Ncrit or NNI (Figure 7). In general, PNI decreased in all treatments as the growing season progressed (Figure 7A and B). However, maize plants did not show visual phosphorus deficiency symptoms under any treatment. The Pcrit- evaluation (Figure 7A) showed that only for the rainfed treatment was $\mathrm{P}$ supply adequate from planting to $120 \mathrm{DAP}$ when maize plants were near physiological maturity. The PNI declined from 108 to 115 DAP, due to the reported remobilisation of phosphorus from leaves and stalk to ears and other reproductive parts of maize plant (Cherbuy et al., 2001; Maillard et al., 2015). The evaluation of the PNI using Pcrit estimated from Ncrit (Pcrit-Ncrit) showed P deficiency during the growing season as presented in Figure $7 \mathrm{~B}$ and $\mathrm{C}$; however, no visual $\mathrm{P}$ deficiency in plants was observed during the research duration.

The comparison of both models showed the superiority of Pcrit-Ncrit over Pcrit, indicating that the critical nitrogen model developed by Plénet and Lemaire (2000) and the N-P relationship developed by Djaman et al. (2013) can be used for both nitrogen and phosphorus status quantification for determining in-season $\mathrm{N}$ and $\mathrm{P}$ deficiencies in maize crops in crop management conditions similar to those presented in this research. There is, however, a need to develop maize critical $\mathrm{N}$ dilution curves for sub-optimal irrigation as the critical $\mathrm{N}$ concentration is lower under water stress (limited irrigation and rainfed crop production conditions) as reported by Errecart et al. (2014). This finding is useful for in-season fertiliser application and adjustments based on crop needs. Overall, plant phosphorus concentrations under the crop, fertiliser and irrigation management practices used in this study fell within the range of the developed phosphorus dilution curves:

$$
\begin{array}{ll}
\mathrm{P} \max =11.63 \times \mathrm{WW}^{-0.57} & \left(\mathrm{R}^{2}=0.99\right) \\
\mathrm{P} \min =4.60 \mathrm{xW}^{-0.451} & \left(\mathrm{R}^{2}=0.97\right)
\end{array}
$$

Historically, critical N and/or P and NNI methods have been developed either only from rainfed or only from irrigated plots; and in some cases data from both settings have been used. Nitrogen fertiliser management and recommendations must consider all potential sources of available $\mathrm{N}$, as well as soil properties, fertiliser manage-
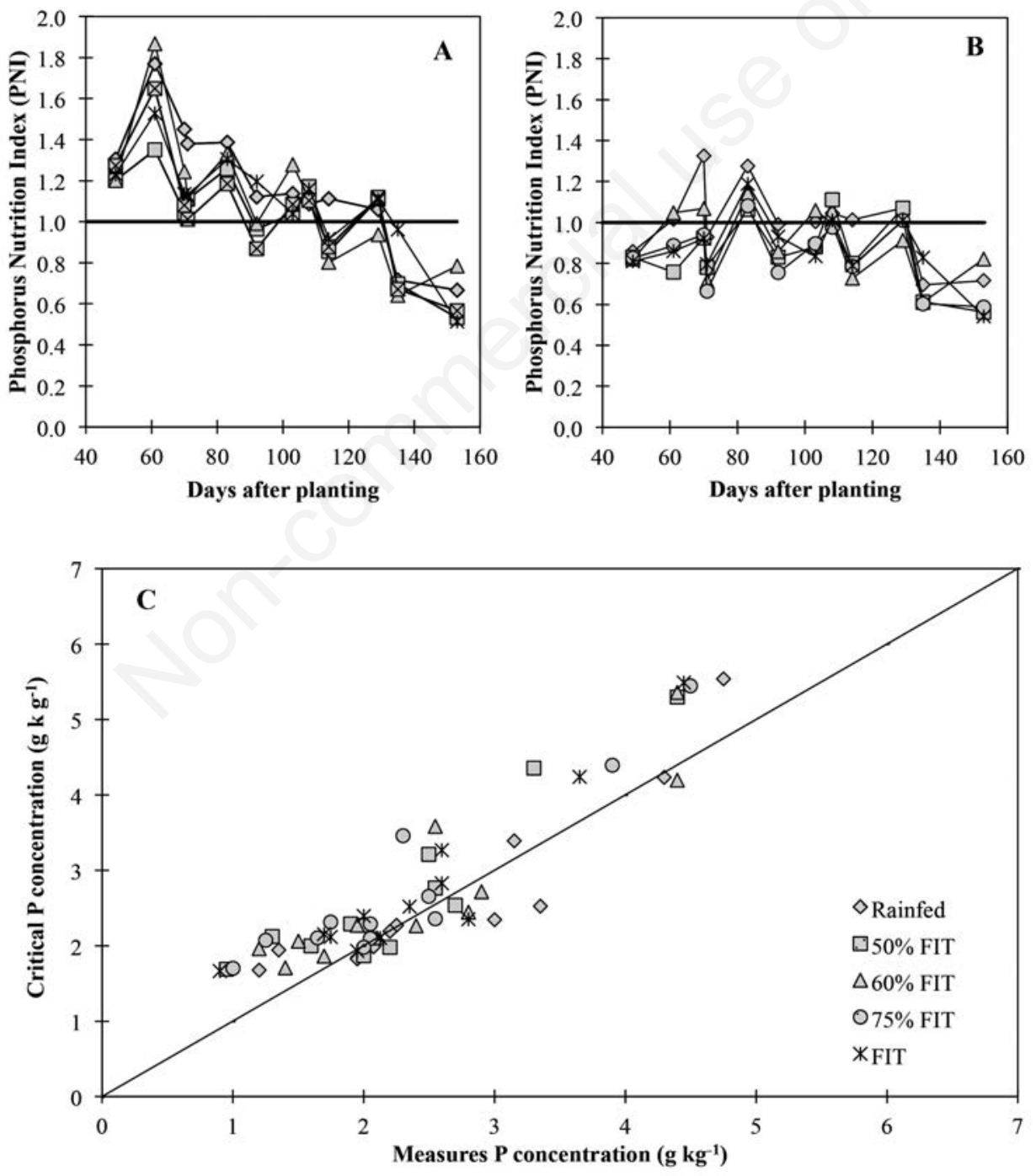

Figure 7. Evaluation of phosphorus nutrition index in maize shoot biomass under fully-irrigated treatment (FIT), 75\% FIT, 60\% FIT, $50 \%$ FIT, and rainfed conditions using: (A) nitrogen $(N)$ and phosphorus (P) relationship; (B) critical P model; and (C) measured P concentration vs critical $P$ concentration relationship. 
ment, and climate effects to accurately estimate crop fertiliser $\mathrm{N}$ requirements (Meisinger, 1984; Oberle and Keeney, 2013) as well as soil water status (e.g., different irrigation levels vs rainfed). Irrigation management and associated soil-water status can substantially affect plant $\mathrm{N}$ uptake and residual soil $\mathrm{N}$ at the end of the season (Djaman et al., 2013). Thus, a method that provides an assessment of critical $\mathrm{N}$ and $\mathrm{P}$ and NNI with respect to irrigation management (full irrigation, limited irrigation and rainfed) is important, because most of the literature currently available do not consider irrigation regime and little attention has been paid to developing strategies to evaluate NNI and determine critical N and P for optimum crop productivity at different irrigation levels. The NNI evaluations and critical $\mathrm{N}$ and $\mathrm{P}$ models studied in this research not only account for the dynamics of $\mathrm{N}$ uptake in irrigated settings, but are based on data from different levels of irrigation and rainfed conditions, which is useful to better represent actual growing conditions in the field environment. Depending on the precipitation amount and distribution and/ or on the complementary irrigation, crops may experience different levels of water stress during certain periods of the growing season. At south central Nebraska, rainfed maize can be as productive as irrigated maize during the wet years (Irmak, 2015). Therefore, the applicability of NNI that was developed for fully-irrigated setting to limited irrigation or water-stressed condition depends on the local climatic conditions. The present study indicated that using NNI previously developed for irrigated conditions provided more effective assessment of $\mathrm{N}$ status within the plant tissue during maize growing season than crtit $\mathrm{N}$ model in our experimental conditions. The NNI was able to capture the degree of $\mathrm{N}$ deficiency or excess on a very short period during growth stage of plants. Thus, coupling rainfed data as well as different levels of irrigation data to evaluate NNI and CritN and CritP dilution curves is perhaps more realistic and there is a need develop similar models under combined rainfed and 60 to $75 \%$ of fully irrigated crop with larger applicability in practice rather than developing these models for only irrigated conditions or for only rainfed settings. Moreover, the association of NNI and PCrit-NCrit to critical N and P models provided better diagnosis of plant $\mathrm{N}$ and $\mathrm{P}$ status under rainfed and limited irrigation conditions while fertiliser recommendations are available only for no water stress or fully irrigation conditions. There is a need of careful interpretation of the Ncrit, Pcrit, Ncrit-Pcrit, and NNI models under water limiting conditions and these models could be coupled with tissue $\mathrm{N}$ and $\mathrm{P}$ concentrations measurement might improve nutrient diagnosis for sustainable fertiliser management that prevent environment pollution while maintaining yield target. Thus, the critical N and NNI methods could be substituted by the soil-plant analysis development (SPAD) meter which is a low-cost, rapid, simple and non-destructive plant nitrogen status assessment tool that provides better solution for nitrogen management at field level, taking into account the position of the leaves on the crop plant and crop growth stage (Ziadi et al., 2008; Prost and Jeuffroy, 2007; Ata-UlKarim et al., 2016; Yuan et al., 2016; Zhao et al., 2016).

\section{Conclusions}

The results of this research indicate that the critical $\mathrm{N}$ and $\mathrm{P}$ dilution curves can enable inferring valuable information and data in terms of $\mathrm{N}$ and $\mathrm{P}$ nutrition of maize crop under different irrigation levels and could be used as a guide to improve $\mathrm{N}$ and $\mathrm{P}$ fertilisation management. Moreover, they can serve as an in-season diagnosis tools for maize $\mathrm{N}$ and $\mathrm{P}$ status to determine the necessity of applying complementary $\mathrm{N}$ and $\mathrm{P}$ fertilisers at different growth stages.
However, additional research is needed involving different nitrogen and phosphorus rates that can determine the potential limitations and boundaries of the present research's findings in developing local critical $\mathrm{N}$ and $\mathrm{P}$ curves under different conditions. Combination of the critical nitrogen dilution model developed by Plénet and Lemaire (2000), the NNI and the relationship between N and P developed by Djaman et al. (2013) is more robust tool for determining critical $\mathrm{N}$ and $\mathrm{P}$ in maize for in-season crop $\mathrm{N}$ status diagnosis for improving the efficiency of fertiliser management for maize production in the study area and similar pedo-climatic conditions.

\section{References}

Ata-Ul-Karim ST, Cao Q, Zhu Y, Tang L, Rehmani MI, Cao WX, 2016. Non-destructive assessment of plant nitrogen parameters using leaf chlorophyll measurements in rice. Front. Plant Sci. 7:18-29.

Barbieri A, Echeverría P, Sainz Rozas HR, Andrade FH, 2013. Nitrogen status in maize grown at different row spacings and nitrogen availability. Canad. J. Plant Sci. 93:1049-58.

Bedoussac L, Justes E, 2010. The efficiency of a durum wheat winter pea intercrop to improve yield productivity and wheat grain protein concentration depends on $\mathrm{N}$ availability during early growth. Plant Soil 330:19-35.

Bélanger G, Claessens A, Ziadi N, 2011. Relationship between P and $\mathrm{N}$ concentrations in maize and wheat leaves. Field Crops Res. 123:28-37.

Bélanger G, Richards JE, 1997. Growth analysis of timothy grown with varying N nutrition. Canad. J. Plant Sci. 77:373-80.

Bélanger G, Richards JE, 1999. Relationship between P and N concentrations in timothy. Canad. J. Plant Sci. 79:65-70.

Bélanger G, Richards JE, 1999. Relationship between P and N concentrations in timothy. Canad. J. Plant Sci. 79:65-70.

Bélanger G, Walsh JR, Richards JE, Milburn PH, Ziadi N, 2001. Critical nitrogen curve and nitrogen nutrition index for potato in eastern Canada. Am. J. Potato Res. 78:355-64.

Bélanger G, Ziadi N, 2008. Phosphorus and nitrogen relationships during spring growth of an aging timothy sward. Agron. J. 100:1757-62.

Bender RR, Haegele JW, Ruffo ML, Below FE, 2013. Nutrient uptake, partitioning, and remobilization in modern, transgenic insect-protected maize hybrids. Agron. J. 105:161-70.

Buljovcic Z, Engels C, 2001. Nitrate uptake ability by maize roots during and after drought stress. Plant Soil 229:125-35.

Chaudhary EH, Ranjha AM, Gill MA, Mehdi SM, 2003. Phosphorus requirement of maize in relation to soil characteristics. Int. J. Agricult. Biol. 5:625-9.

Chen D, Shiwen W, Binglin X, Beibei C, Xiping D, 2015. Carbon/nitrogen imbalance associated with drought-induced leaf senescence in Sorghum bicolor. PLoS One. 10:e0137026.

Chen P, Zhu Y, 2013. A new method for winter wheat critical nitrogen curve determination. Agron. J. 105:1839-46.

Chen X, Zhang F, Cui Z, Li J, Ye Y, Yang Z, 2010. Critical grain and stover nitrogen concentrations at harvest for summer maize production in China. Agron. J. 102:289-95.

Cherbuy B, Joffre R, Gillon D, Rambal S, 2001. Internal remobilization of carbohydrates, lipids, nitrogen and phosphorus in the Mediterranean evergreen oak Ouercus ilex. Tree Physiol. 21:9-17.

Ciampitti IA, Camberato JJ, Murrell ST, Vyn TJ, 2013. Maize nutrient accumulation and partitioning in response to plant 
density and nitrogen rate: I. Macronutrients. Agron. J. 105:783-95.

Corre-Hellou G, Fustec J, Crozat Y, 2006. Interspecific competition for soil $\mathrm{N}$ and its interaction with $\mathrm{N} 2$ fixation, leaf expansion and crop growth in pea-barley inter crops. Plant Soil 282:195-208.

Djaman K, Irmak S, 2012. Soil water extraction patterns, crop, irrigation, and evapotranspiration water use efficiency under full and limited irrigation and rainfed conditions. Trans. ASABE 55:1223-38.

Djaman K, Irmak S, Martin DL, Ferguson RB, Bernards ML, 2013. Plant nutrient uptake and soil nutrient dynamics under full and limited irrigation and rainfed maize production. Agron. J. 105:527-38.

Dordas AC, 2011. Nitrogen nutrition index and its relationship to $\mathrm{N}$ use efficiency in linseed. Eur.n J. Agron. 34:124-32.

Duru M, 2004. Simplified nitrogen assessment of orchardgrass swards. Agron. J. 96:1598-605.

Duru M, Ducrocq H, 1997. A nitrogen and phosphorus herbage nutrient index as a tool for assessing the effect of $\mathrm{N}$ and $\mathrm{P}$ supply on the dry matter yield of permanent pastures. Nutr. Cycling Agroecosyst. 47:59-69.

Duru M, Ducrocq H, 1997. A nitrogen and phosphorus herbage nutrient index as a tool for assessing the effect of $\mathrm{N}$ and $\mathrm{P}$ supply on the dry matter yield of permanent pastures. Nutr. Cycling Agroecosyst. 47:59-69.

Errecart PM, Agnusdei MG, Lattanzi FA, Marino MA, Berone GD 2014. Critical nitrogen concentration declines with soil water availability in tall fescue. Crop Sci. 5:318-30.

Ferrario-Mery S, Valadier MH, Foyer CH, 1998. Overexpression of nitrate reductase in tobacco delays drought-induced decreases in nitrate reductase activity and mRNA. Plant Physiol. 117:293-302.

Flénet F, Guérif M, Boiffin J, Dorvillez D, Champolivier L, 2006. The critical $\mathrm{N}$ dilution curve for linseed (Linum usitatissimum L.) is different from other C3 species. Eur. J. Agron. 24:36773.

Foyer CH, Valadier MH, Migge A, Becker TW, 1998. Droughtinduced effects on nitrate reductase activity and mRNA and on the coordination of nitrogen and carbon metabolism in maize leaves. Plant Physiol. 117:283-92.

Gee WG, Or D, 2002. Particle-size analysis. In: J. Dane andG.C. Topp (Eds.), Methods of soil analysis. Book Series: 5. Part 4. Soil Science Society of America, USA, pp. 255-293.

Gehl RJ, Schmidt JP, Stone LR, Schlegel AJ, Clark GA. 2005. In situ measurements of nitrate leaching implicate poor nitrogen and irrigation management on sandy soils. J. Environ. Qual. 34:2243-54.

Gonzalez-Dugo V, Durand JL, Gastal F, 2010. Water deficit and nitrogen nutrition of crops. Agron. Sustain. Develop. 30:529-44.

Gonzalez-Dugo V, Durand JL, Gastal F, Picon-Cochard C, 2005. Short-term response of the nitrogen nutrition status of tall fescue and Italian ryegrass swards under water deficit. Austr. J. Agricult. Res. 56:1269-76.

Greenwood DJ, Karpinets TV, Zhang K, Bosh-Serra A, Boldrini A, Karawulova L, 2008. A unifying concept for the dependence of whole-crop N:P ratio on biomass: theory and experiment. Annals Bot. 102:967-77.

Greenwood DJ, Lemaire G, Gosse G, Cruz P, Draycott A, Neeteson JJ, 1990. Decline in percentage N of C3 and C4 crops with increasing plant mass. Annals Bot. 66:425-36.

Heckman JR, Jokela W, Morris T, Beegle DB, Sims JT, Coale FJ, Herbert S, Griffin T, Hoskins B, Jemison J, Sullivan WM,
Bhumbla D, Estes G, Reid WS, 2006. Soil test calibration for predicting corn response to phosphorus in the Northeast USA. Agron. J. 98:280-8.

Herrmann A, Taube F, 2004. The range of the critical nitrogen dilution curve for maize (Zea mays L.) can be extended until silage maturity. Agron. J. 96:1131-8.

Houlès V, Guérif M, Mary B, 2007. Elaboration of a nitrogen nutrition indicator for winter wheat based on leaf area index and chlorophyll content for making nitrogen recommendations. Eur. J. Agron. 27:1-11.

Hu C, Saseendran SA, Green TR, Ma L, Li X, Ahuja LR, 2006. Evaluating nitrogen and water management in a double-cropping system using RZWQM. Vadose Zone J. 5:493-505.

Hu T, Shaozhong K, Li F, Zhang J, 2009. Effects of partial rootzone irrigation on the nitrogen absorption and utilization of maize. Agricult. Water Manage. 9:208-14.

Irmak S, 2010. Nebraska water and energy flux measurement, modeling, and research network (NEBFLUX). Trans. ASABE 53:1097-15.

Irmak S, 2015. Inter-annual variation in long-term center pivotirrigated maize evapotranspiration (ET) and various water productivity response indices: Part I. Grain yield, actual and basal ET, irrigation-yield production functions, ET-yield production functions, and yield response factors. J. Irrig. Drain. Engine. ASCE 141:04014068-1-17.

Irmak S, Istanbulluoglu E, Irmak A, 2008. An evaluation of evapotranspiration model complexity against performance in comparison with Bowen ratio energy balance measurements. Trans. ASABE 51:1295-310.

Jensen ES, 1996. Grain yield, symbiotic N2 fixation and interspecific competition for inorganic $\mathrm{N}$ in pea-barley intercrops. Plant Soil 182:25-38.

Jeuffroy MH, Recous S, 1999. Azodyn: a simple model simulating the date of nitrogen deficiency for decision support in wheat fertilization. Eur. J. Agron. 10:129-44.

Justes E, Mary B, Meynard JM, Machet JM, Thelier-Huche L, 1994. Determination of a critical nitrogen dilution curve for winter wheat crops. Annals Bot. 74:397-407.

Kamprath EJ, 1987. Enhanced phosphorus status of maize resulting from nitrogen fertilization of high phosphorus soils. Soil Sci. Soc. Am. J. 51:1522-6.

Kumar S, Dey P, 2011. Effect of different mulches and irrigation methods on root growth, nutrient uptake, water use efficiency and yield of strawberry. Sci. Horticult. 127:318-24.

Lemaire G, Denoix A, 1987. Croissance estivale en matière sèche de peuplements de fétuque élevée (Festuca arundinacea Schreb.) et de dactyle (Dactylis glomerata L.) dans l'Ouest de la France. I. Etude en conditions de nutrition azotée et d'alimentation hydrique non limitantes. Agronomie 7:373-80.

Lemaire G, Gastal F, 1997. N uptake and distribution in plant canopies. In: G. Lemaire (Ed.), Diagnosis of the nitrogen status in crops. Springer-Verlag, Berlin, Germany, pp. 3-43.

Lemaire G, Gastal F, 2009. Quantifying crop responses to nitrogen deficiency and avenues to improve nitrogen use efficiency. In: V.O. Sadras and D.F. Calderini (Eds.), Crop physiology. Applications for genetic improvement and agronomy. Elsevier, Burlington, MA, USA, pp. 171-211.

Lemaire G, Gastal F, Salette J, 1989. Analysis of the effect of N nutrition on dry matter yield of a sward by reference to potential yield and optimum $\mathrm{N}$ content. pp 179-180 in Proc. Int. Grassl. Congr., XVI, Nice, France, 4-11 Oct. 1989. Association Française pour la Production Fourragère, Versailles, France. 
Lemaire G, Jeuffroy MH, Gastal F, 2008. Diagnosis tool for plant and crop $\mathrm{N}$ status in vegetative stage: theory and practices for crop N management. Eur. J. Agron. 28:614-24.

Lemaire G, Salette J, 1984. Relationship between growth and nitrogen uptake in a pure grass stand. I. Environmental effects. Agronomie 4:423-30 [In French].

Li W, He P, Jin J, 2012. Critical nitrogen curve and nitrogen nutrition index for spring maize in north-est China. J. Plant Nutr. 35:1747-61.

Li W, He P, Jin J, 2012. Critical nitrogen curve and nitrogen nutrition index for spring maize in North-East China. J. Plant Nutr. 35:1747-61.

Li XX, Hu CS, Delgado JA, Zhang YM, Ouyang ZY, 2007. Increased nitrogen use efficiencies as a key mitigation alternative to reduce nitrate leaching in north China Plain. Agricult. Water Manage. 89:137-47.

Lindquist JL, Evans SP, Shapiro CA, Knezevic SZ, 2010. Effect of nitrogen addition and weed interference on soil nitrogen and corn nitrogen nutrition. Weed Technol. 24:50-8.

Lory JA, Scharf PC, 2003. Yield goal versus delta yield for predicting fertilizer nitrogen need in corn. Agron. J. 95:994-9.

Maillard A, Diquélou S, Billard V, Laîné P, Garnica M, Prudent M, Garcia-Mina JM, Yvin JC, Ourry A, 2015. Leaf mineral nutrient remobilization during leaf senescence and modulation by nutrient deficiency. Front. Plant Sci. 6:317.

Meisinger JJ, 1984. Evaluating plant-available nitrogen in soilcrop systems. In: R.D. Hauck (Ed.), Nitrogen in crop production. ASA, CSSA, and SSSA, Madison, WI, USA, pp 391-416.

Morel C, Plenchette C, Fardeau JC, 1992. Reasoned phosphorus fertilization in a wheat crop. Agronomie 12:565-79 [In French].

Munson RD, Nelson WL, 1990. Principles and practices in plant analysis. In: R.L. Westerman (Ed.), Soil testing and plant analysis. 3rd ed. SSSA Book Ser. 3. SSSA, Madison, WI, USA.

Naud C, Makowski D, Jeuffroy MH, 2009. Leaf transmittance measurements can improve predictions of the nitrogen status for winter wheat crop. Field Crops Res. 110:27-34.

Nye P, Tinker P, 1977. Solute movement in the soil-root system. University of California Press, Berkeley, USA:

Oberle SL, Keeney DR, 2013. Factors influencing corn fertilizer N requirements in the Northern U.S. Corn Belt. J. Prod. Agric. 3:527-34.

Onillon B, Durand JL, Gastal F, Tournebize R, 1995. Drought effects on growth and carbon partitioning in a tall fescue sward grown at different rates of nitrogen fertilization. Eur. J. Agron. 4:91-9.

Plénet D, Lemaire G, 2000. Relationships between dynamics of nitrogen uptake and dry matter accumulation in maize crops. Determination of critical N concentration. Plant Soil 216:65-82.

Prost L, Jeuffroy M-H, 2007. Replacing the nitrogen nutrition index by the chlorophyll meter to assess wheat $\mathrm{N}$ status. Agron. Sustain. Dev. 27:321-30.

Rashi M, Iqbal M, 2012. Effect of phosphorus fertilizer on the yield and quality of maize (Zea mays L.) fodder on clay loam soil. J. Animal Plant Sci. 22:199-203.

Rashid MT, Voroney P, Parkin G, 2005. Predicting nitrogen fertilizer requirements for corn by chlorophyll meter under different $\mathrm{N}$ availability conditions. Canad. J. Soil Sci. 85:149-59.

Rayment GE, Lyons DJ, 2011. Soil chemical methods Australasia. Collingwood: CSIRO Publishing.

Robredo A, Perez-Lopez U, Miranda-Apodaca J, Lacuesta M, Mena-Petite A, Munoz-Rueda A, 2011. Elevated CO2 reduces the drought effect on nitrogen metabolism in barley plants dur- ing drought and subsequent recovery. Environ. Exper. Botany 71:399-408.

Rosenstock T, Liptzin D, Six J, Tomich T, 2013. Nitrogen fertilizer use in California: Assessing the data, trends and a way forward. California Agric. 67:68-79.

Rudnick DR, Irmak S, 2014. Spatial and temporal maize soil-water extraction (depletion) dynamics: Part I. Development and evaluation of a soil water-extraction model. Trans. ASABE 57:431-44.

Salette J, Huché L, 1991. Diagnosis of the mineral nutrition status of a pasture through herbage analysis: Principles, implementation, examples. Fourrages 125:3-18 [In French, with English abstract].

Salette J, Huché L, 1991. Diagnosis of the mineral nutrition status of a grassland by vegetation analysis: principles, practice and examples. Fourrages 125:3-18.

Seiffert S, Kaselowsky J, Jungk A, Claassen N, 1995. Observed and calculated potassium uptake by maize as affected by soil water content and bulk density. Agron. J. 87:1070-7.

Shapiro AC, Ferguson RB, Hergert GW, Wortmann CS, Waters DT, 2008. Fertilizer suggestions for corn. University of Nebraska-Lincoln Extension article CE117. P 6.

Shapiro CA, Ferguson RB, Ilergen GW, Dobcrmann AR, Wortrnann CS, 2003. Fertilizer suggestions for corn. University of Nebraska. NcbGuide 074-174-A. Lincoln, NE, USA. Available from: http://www.ianrpubs. unl.edulsendlt'gl 74.pdf

Sheehy JE, Dionora MJA, Mitchell PL, Peng S, Cassman KG, Lemaire G, Williams RL, 1998. Critical nitrogen concentrations: implications for high yielding rice (Oryza sativa L.) cultivars in the tropics. Field Crops Res. 59:31-41.

Singh G, Singh B, 2009. Effect of varying soil water stress regimes on nutrient uptake and biomass production in Dalbergia sissoo seedlings in Indian desert. J. Forest. Res. 20:307-13.

Skonieski FR, Viégas J, Cruz P, Nornberg JL, Bermudes RF, Gabbi AM, 2012. Dynamics of nitrogen concentration on intercropped ryegrass. Acta Scientiarum. Animal Sci. 34:1-6.

Smyth TJ, Cravo MS, 1990. Critical phosphorus levels for corn and cowpea in a Brazilian Amazon Oxisol. Agron. J. 82:309-12.

Steffens D, 1994. Phosphorus release kinetics and extractable phosphorus after long-term fertilization. Soil Sci. Soc. Am. J. 58:1702-8.

Stockle CO, Debaeke P, 1997. Modelling crop nitrogen requirements: a critical analysis. Eur. J. Agron. 7:161-9.

Tei F, Benincasa P, Guiducci M, 2002. Critical nitrogen concentration in processing tomato. Eur. J. Agron. 18:45-55.

Tiessen H, Stewart JWB, Oberson A, 1994. Innovative soil phosphorus availability indices: Assessing organic phosphorus. In: J.L. Havlin (Ed.), Soil testing: prospects for improving nutrient recommendations. SSSA Spec. Publ. 40. ASA and SSSA, Madison, WI, USA, pp 143-162.

Ulrich A, Berry WL, 1961. Critical phosphorus levels for lima bean growth. Plant Physiol. 36:626-32.

USDA-NASS. 2008. United States Department of AgricultureNational Agricultural Statistics Service. Available from: http://www.nass.usda.gov

Van Oosterom EJ, Carberry PS, Muchow RC, 2001. Critical and minimum $\mathrm{N}$ contents for development and growth of grain sorghum. Field Crops Res. 70:55-73.

Walworth JL, Carling DE, Michaelson GJ, 1992. Nitrogen sources and rates for direct-seeded and transplanted lettuce. Horticult. Sci. 27:228-30.

Westfall DG, Whitney D.A, Brandon DM, 1990. Plant analysis as an aid in fertilizing small grain. In: R.L. Westerman (Ed.), Soil testing and plant analysis. SSSA Book Series 3. Soil Science 
Society of America, Madison, WI, USA, pp. 495-519.

Wortmann CS, Dobermann AR, Ferguson RB, Hergert GW, Shapiro CA, Tarkalson DD, Walters DT, 2009. High-yielding corn response to applied phosphorus, potassium, and sulfur in Nebraska. Agron. J. 101:546-55.

Xu ZZ, Zhou GS, 2006. Nitrogen metabolism and photosynthesis in Leymus chinensis in response to long-term soil drought. J. Plant Growth Regul. 25:252-66.

Xue X, Wang J, Wang Z, Guo W, Zhou Z, 2007. Determination of a critical dilution curve for nitrogen concentration in cotton. J. Plant Nutr. Soil Sci. 170:811-7.

Yaseen R, Shafi W, Ahmad MS, Rana M, Salim SA, Qaisrani J, 2014. Effect of deficit irrigation and mulch on soil physical properties, growth and yield of maize. Environ. Ecol. Res. 2:122-37.

Yu W, Chi SY, Ning T, Tian SZ, Li ZJ, 2013. Coupling effects of irrigation and phosphorus fertilizer applications on phosphorus uptake and use efficiency of winter wheat. J. Integr. Agricult. 12:263-72.

Yuan Z, Ata-Ul-Karim ST, Cao Q, Lu Z, Cao W, Zhu Y, 2016. Indicators for diagnosing nitrogen status of rice based on chlorophyll meter readings. Field Crops Res. 185:12-20.
Yue S, Meng Q, Zhao R, Li F., Chen X, Zhang, F Cui Z, 2012. Critical nitrogen dilution curve for optimizing nitrogen management of winter wheat production in the North China Plain. Agron. J. 104:523-9.

Zhao B, Liu Z, Ata-Ul-Karim ST, Xiao J, Liu Z, Qi A, 2016. Rapid and nondestructive estimation of the nitrogen nutrition index in winter barley using chlorophyll measurements. Field Crops Res. 185:59-68.

Zia MS, Amin R, Qayum FE, Aslam M, 1988. Plant tissue concentration and uptake of phosphorus by maize as affected by level of P fertilizer. Pak. J. Agricult. Res. 9:335-8.

Ziadi N, Belanger G, Cambouris AN, Tremblay N, Nolin MC, Claessens A, 2007. Relationship between $\mathrm{P}$ and $\mathrm{N}$ concentrations in corn. Agron. J. 99:833-41.

Ziadi N, Brassard M, Bélanger G, Cambouris AN, Tremblay N, Nolin MC, Claessens A, Parent L, 2008. Critical nitrogen curve and nitrogen nutrition index for corn in eastern Canada. Agron. J. 100:271-6.

Ziadi N, Brassard M, Bélanger G, Claessens A, Tremblay N, Cambouris AN, Nolin MC, Parent LE, 2008. Chlorophyll measurements and nitrogen nutrition index for the evaluation of corn nitrogen status. Agron. J. 100:1264-73. 